\title{
Brussels enters debate over effects of nuclear tests on environment
}

Paris. France last week agreed to talks with the European Commission about the potential effects on the environment of its planned nuclear tests in the Pacific, and to let the commission visit its Mururoa Atoll test site to verify the control measures being taken.

The talks, due to be held today (Thursday 24 August), will focus on an extremely technical report on the precautions being taken by France to prevent radioactive emissions, which was submitted by France last month at the commission's request. The terms of the commission's mission to Mururoa will also be discussed at the meeting.

"This time, we considered we should take the initiative, and not wait until this information came to us after the tests," says Thierry Daman, a spokesman for the commission. The commission has argued that the 1957 Euratom treaty gives it the power to ensure that the safety measures accompanying tests are sufficient to safeguard public health.

Under the terms of the Euratom treaty, the commission can demand extra safety measures if it considers the tests to be "particularly dangerous". If, in addition, the tests risk affecting another member state Britain has sovereignty over the Pitcairn Islands, $900 \mathrm{~km}$ from Mururoa - France would need authorization from the commission before proceeding.

But if the new commission, which was appointed earlier this year, is trying to flex its Euratom muscles, observers are sceptical that it would take the political risk of classing the tests - which France considers are an area of national sovereignty - as "particularly dangerous".

Moreover, opposition to the French tests on the grounds that radiation may escape into the environment seems to be based more on speculation than on hard evidence, according to the various studies of the 41 atmospheric tests and 138 underground explosions that France has carried out in the Pacific.

A report submitted to a meeting last week of environment ministers from South Pacific countries, by a group of scientists from Australia and New Zealand, concluded, for example, that concentrations of radioisotopes around the atoll were low, and that potential releases through rupturing of the bedrock were unlikely.

But the report, which was largely drawn from three independent scientific studies carried out during the past decade, added that it was difficult to draw firm conclusions given that the studies had not been allowed complete access to the atoll.

The information office of the French armed forces (SIRPA), while hardly an impartial observer, also claims that levels of artificial atmospheric radioactivity at Mururoa are lower than those of natural radioactivity in either nearby Tahiti or in France. SIRPA concedes that radioactive residues are present in the lagoon, but claims that these result from past atmospheric tests, and that their levels are similar to those found in the Baltic and North Seas.

"Everybody now agrees that radioactivity at the surface of the atoll is low", says Abraham Behart, a member of the Association of French Physicians for the Prevention of Nuclear War, who took part in studies of the health of Polynesian populations in 1990.

But Behart does not discount the hypothesis, proposed in the newspaper Le Monde by Pierre Vincent - a vulcanologist from the Observatoire de Physique du Globe at Clermont-Ferrand - that further tests could rupture the rock and release radionu-

\author{
IMAGE \\ UNAVAILABLE \\ FOR COPYRIGHT \\ REASONS
}

\section{Atom cloud has silver lining}

San Francisco. Nuclear weapons laboratories in the United States believe funding is nearly certain for a series of major projects aimed at monitoring and verifying the country's weapons stockpile, following the announcement by President Bill Clinton that the United States will press for a ban on all nuclear tests, no matter how small, from next year (see Nature 376, 540; 1995).

Although Clinton's statement did not refer directly to either the \$123.8-million Dual-Axis Radiographic Hydrotest (DARHT) at the Los Alamos National Laboratory or the \$4.5-billion National Ignition Facility (NIF) at the Lawrence Livermore National Laboratory, both in California, it implied a promise of support for these projects, laboratory officials said.

According to observers, funding for a series of robust programmes at all three national weapons laboratories is virtually ensured by Clinton's emphasis that the United States would need safeguards to maintain a reliable stockpile under a comprehensive test ban - such as research to improve treaty monitoring, programmes in theoretical and exploratory nuclear technology, and maintaining the capacity to resume nuclear testing. "The general defence pie is shrinking, but some of the pie will grow," says Geer, a spokesman for Sandia National Laborarories, based in Albuquerque, New Mexico.

It is too soon to say which specific programmes will benefit. But a ban on hydronuclear tests, yielding less than four pounds of TNT equivalent, will mean greater reliance on computer simulation techniques, says
Kathy DeLucas, a spokeswoman for Los Alamos, and an increased justification for the \$794 million Accelerated Strategic Computing Initiative. This ambitious five-year programme is aimed at linking the three laboratories with hardware manufacturers to develop extremely powerful three-dimensional modelling techniques.

DeLucas also says that Clinton's decision will provide "stronger arguments" for the continued funding of the DARHT facility at Los Alamos, which has been vigorously opposed by environmentalists. This highexplosives firing site, which is equipped with two state-of-the-art flash X-ray machines as a new tool for evaluating nuclear weapons, is due to seek a second round of funding in 1997.

Similarly, Lawrence Livermore says the new situation improves the prospects for its planned National Ignition Facility, which will study fusion using enormous lasers that can unleash up to 500 terawatts of energy onto a pellet of deuterium and tritium, compressing the pellet, heating it to more than a million degrees and triggering sustained thermonuclear fusion.

Such programmes are needed to retain competence in nuclear weapons, argue the laboratories. "The foundation of our capability has always been the competent experts on whom we rely", says C. Paul Robinson, president of Sandia National Laboratories. "It is crucial that we maintain the ability to keep these experts immersed in the relevant technologies that are so unique to nuclear weapons systems."

Sally Lehrman 